\title{
Evaluation Study: Implementation of Training Program for Developing Instructional Media Based on Radio and Television
}

\author{
${ }^{1}$ Zainuddin Nasution, ${ }^{2}$ Nurdin Ibrahim, ${ }^{3}$ Wardani Rahayu \\ \{1'zainasution@gmail.com, ${ }^{2}$ nurdin1349@gmail.com, ${ }^{3}$ wardani9164@yahoo.com $\}$ \\ ${ }^{1}$ Ministry of Education and Culture, Indonesia \\ ${ }^{2,3}$ Universitas Negeri Jakarta, Indonesia
}

\begin{abstract}
The purpose of this study was to evaluate the training program for the development of radio and television-based learning media using a combination of the Discrepancy model evaluation and Kirkpatrick's. The study used both qualitative and quantitative methods, along with an evaluation design meant to determine the directions and frameworks for evaluation. The analysis design consisted of the evaluation stages, measured aspects, data sources, and collected information. Data collection techniques involved observation, interviews, and questionaires. The evaluation results showed that learning outcomes changed in behavior and the impact of training on the participants were still not in accordance with the established criteria. Nevertheless, it is still in the category of being quite effective. The criteria is set from effective to very effective. Overall the training on the development of radio and television-based learning media implemented by Pustekkom is quite effective, though several improvements can be made.
\end{abstract}

Keywords: Teacher Training, Discrepancy Evaluation Model, Kirkpatrick Evaluation Model

\section{Introduction}

Information technology forms the basis of human life in the era of industrial revolution 4.0 also known as the fourth world industrial revolution. To encourage national competitiveness in the age of industrial revolution 4.0, the proper preparation of more innovative learning systems that are responsive and reliable is of great necessity. In recent times, the professionalism of most Indonesian teachers is observed to be very questionable because they lack adequate competencies and the requirements to enhance learning especially in the application of ICT.

The study of the Ministry of Education and Culture's Balitbang Policy and Research Center in 2012 showed that teachers, both in elementary and junior high school, who carried out the competency test had an average score of less than $38.0 \%$. These results were categorized as inadequate, falling below the the satisfying level of 70.0-100. Although a series of efforts had been done to improve competence levels, the results showed there were no significant change. In 2013 the average score was only 42.25 while in 2015 was 53.02. the overall conclusion was that the competence levels of Indosian teachera are significantly low.

The Pustekkom (ICT Center) as one of the institutions under the Ministry of Education and Culture vested with the responsibility of developing ICT-based learning models, has engaged in some training to enhance teachers' competencies especially in the use of ICT for learning. 
Information and communication technologies (ICT) have a positive influence on educational activities [1]. As for the positive influence of the use of ICT in education such as; speed up access to a range of teacher learning resources, speed up the administration of teachers, help teachers explain the material that is abstract and complicated, and facilitate teachers in the report its performance to the Government portal. One of the media that are very effective to use as a learning medium is television which consistently motivated students and draws their interests in learning [2]. In principle, the students are more interested in a message delivered by audio and visual which is easier to understand. Besides, television can also display reality and circumstances directly and give the emphasis of an important matter. In addition motivation in learning, television can improve memory. Edgar Dale reveals that in understanding something better when the material will also utilize the sense of sight than just hearing. [3].

The utilization of ICT in the learning process uses the 2013 curriculum which shows the learning centered on learners. The use of ICT in training also enhance the efficiency of teachers during the teaching process [4]. Pustekom developed a model of learning-based media like the internet, television, radio, and film [5]. Since the year 2005 the Ministry of education and culture, in cooperation with the various parties have provided training to teachers across Indonesia in the field of ICT utilization ( PE-ICT) for learning. The training aims to enhance teachers ability by making learning materials in the form of radio and television. This training program is for teachers of elementary, junior and high school level both public and private which were about 40 persons in every province. The number of annual participants is approximately 1360 attendees from 34 regions. [6].

However, during this period, Pustekom has not only engaged in the monitoring and evaluation of the training but also ensuring that the implementation of the training is effective. The impacts of the training, as well as the participants' behavior, has always been neglected. In regards to this, the training program needs to be evaluated. The evaluation will cover the following areas; planning (definition and installation), the reaction of the participants, the results of learning, work behavior and impact (result) obtained concerning the knowledge and skills of participants in utilizing ICT after returning to their workplace. With comprehensive research and proper analysis, the behavior change and impacts that occurred on the trainees will be seen.

Evaluation is a process description influenced by some scientific procedures, data collection, and submission of information in the form of performance useful for decision making. The analysis of the references of the subject-oriented program was in the way of question insertion about the level to which the program has achieved the desired goals [7]. The Evaluation of the program sought to gather information about some aspects of a program to make essential decisions. The choices made formed part of a performance assessment indicators at each stage of the evaluation in three categories, namely low, moderate and high [8]. According to Musa, the evaluation program is an activity which gained an overview of the state of an object done programmatically, systematic with a clear direction and purpose [9]. Furthermore, Rutman explained that the evaluation of the program involves the application of scientific methods in measuring the implementation and results of the program used as the basis for a decision [10]. Based on some of the concepts, the researchers concluded that evaluation is an assessment that is conducted systematically and objectively against an activity, project, program, strategy, policy, topic, theme, sector, operation or institution.

The evaluation model of DEM (Discrepancy Evaluation Model) developed by Malcolm Provus in 1976. Sees the gap between a standard program with actual conditions (performance). Provus suggests that evaluation is a systematic process which analyses whether the running program complies with the prescribed standards or not. The focal point at the difference between 
performance and standards which became the reason why Provus mentions the concept with the name of the discrepancy [10]. The DEM process is a series of steps and contents of a category that finds a comparison between the achievement of a program with a standard, identifying the standards used as comparisons in the future. Provus stated that each program has a life cycle because the program comprises of development steps, evaluation activities defined as the process of merging in each component so that it becomes a whole unit [11]. Kirkpatrick's evaluation model has widely used in evaluating training programs. He developed a conceptual framework to help determine what data would be captured in the HRD analysis. There are four levels in this model, which are; reaction, learning, behavior, and results. The first stage of the Kirkpatrick evaluation model is a pure reaction evaluation that measures how well the participants like the training program [12]. According to Kirkpatrick, to assess learning outcomes can be done with a comparison group. Groups that take part in training and nontraining groups compared in their development over a period. It can also do by comparing the results of the pretest with posttest, written tests or performance tests. Kirkpatrick's third level of evaluation is behavior. This level refers to the extent to which students apply what they have learned during education [13].

\section{Methodology}

The study used both qualitative and quantitative methods. It also utilized an evaluation design to determine directions and frameworks for an appraisal. The design consisted of the evaluation stages, measured aspects, data sources, and collected informations.

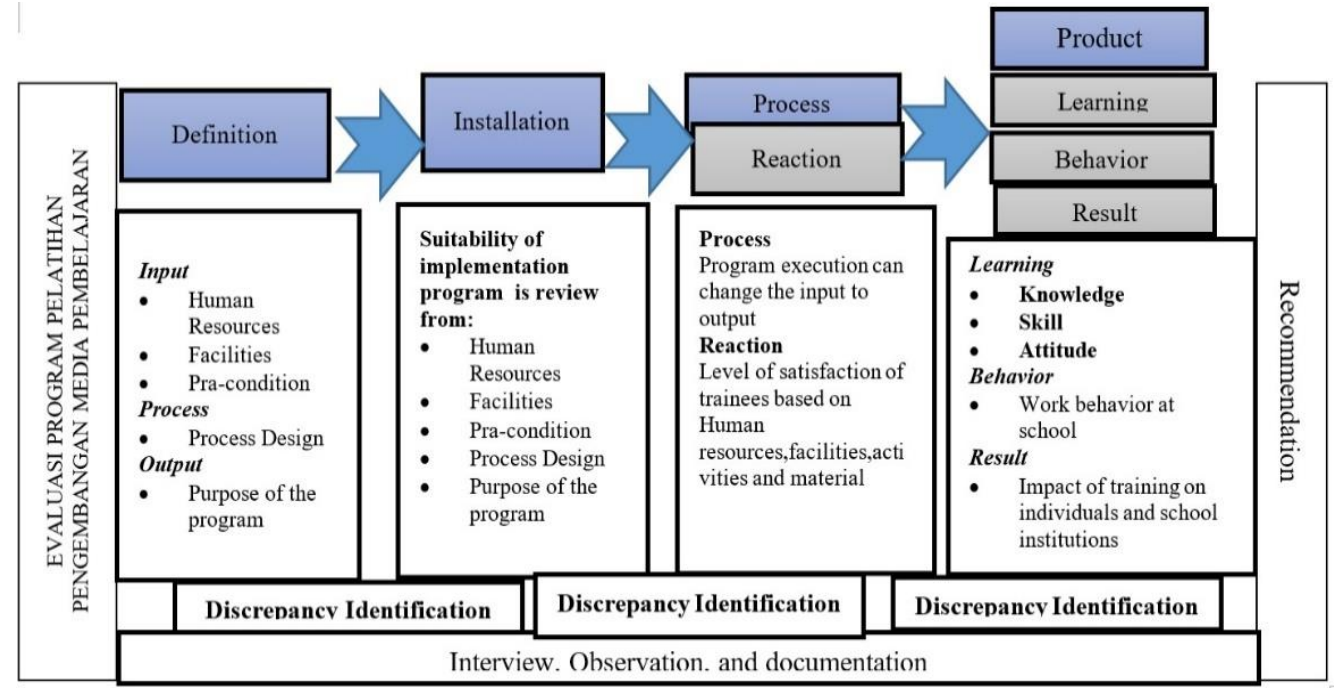

Fig. 1.Design evaluation Implementation of Training Program for Developing Instructional Media Based on Radio and Television.

Datas was collected through observation, interviews, questionnaires. It also used a combination of the Discrepancy evaluation model (DEM) and Kirkpatrick. The following is the evaluation design of a training program for the development of radio and television-based learning media. The evaluation study took 9 (nine) out of 34 (thirty-four) provinces for 
collecting data, and they include the Province of North Sumatra, Banten, DKI Jakarta, West Java, Central Java, East Java, Southeast Sulawesi, North Maluku, and Papua.

The data analysis technique used in this evaluation study is the Milles and Huberman technique, which consists of three flows of activities that co-occur. The flow consists of data reduction, data presentation, and conclusion drawing. [14] The quantitative data of this research are a descriptive analysis which used measures of centralized tendencies (mean, median, and mode). After the data analysis, this study has some results compared with pre-determined evaluation criteria. (See at https://osf.io/ahpbv/)

\section{Results and Discussion}

Overall, the training program was categorized as effective. There are several phases that were still less effective, such as the Installation and Product stages. During the installation phase, the suitability of the training participants and the involved Human Resources was not in accordance with the design of the training set. In some locations participants were only from high school level yet it was expected to encompass all levels, and therefore this does not support the achievement of the training targets. Regarding human resources, the instructors were not optimal in covering the training materials with the participants, probably 40 in number, consisting of one practical insructor and one theoritical instructor. During the practice session, the instructors to serve all participants, especially with diverse abilities. The results of the observations indicated that in some areas, the practical instructors were assisted by the theoritical mentors who did not mastere all the technical development of radio and televisionbased learning media.

In addition, at the installation stage, conformity between the implementation of the training and the achievement of program objectives also fell in the less-effective category. The purpose of this training program was to help the participants be able to make radio and television-based teaching materials in accordance with their respective subjects. During the training program, not all participants can produce teaching materials appropriate to the subjects within 3 days. That time-frame is indeed not enough considrering the fact that they had to get theoretical materials on the model and design of the integrated ICT learning as well as manufacturing techniques. It clearly showed the relationship between the achievement of learning objectives with participants and the human resources involved in implementing the training program. The outcome of 40 people with diverse abilities taught by 2 instructors within 3 days still falls in the category of quite effective, though not in accordance with the established criterias of effective or very effective.

In the Product stage, the variables were still not in accordance with the predetermined criteria. At this stage, learning outcomes, changes in behavior and the impact of the training on the participants were low. Nevertheless, the results still fell in the category of quite effective with the criteria set from effective to very effective.

Donald and James Kirkpatrick suggested several requirements needed to create an effective training program. One of them is that the training program should be able to facilitate participants to gain competencies. [15]. Regarding the training program, the achievement of the objectives has not been optimally achieved yet. Thus, it can be concluded that the training in the development of radio and television-based learning media has not yet facilitated the participants in their quest to achieve the learning objectives optimally. 
The training program basically contains learning activities that are intentionally designed and developed to create learning processes in participants. The participants were to have have various abilities including knowledge; skill; and attitude through the learning process.[16]. In order to create an effective and efficient training, the program needs to be well designed and developed.

Learning outcomes, for instance, knowledge, skills and attitudes, are the product stages in this study. From the results of the study, the product stage was still not yet included in the category of effective as specified in the criteria. This training program was actually designed and developed in reference to the instructional design of Dick \& Carey. The steps started from determining the training objectives or competencies to determining the form or variety of tests and assessments that was used to determine the participants' learning outcomes. The outcomes were important because they were a product of the training program. This was consistent with what Brandt said, that by the end the designer had to focus on the instructional design model by producing products that contain measurable objectives and results.[17].

\section{Conclusion}

Evaluation results show that learning outcomes, changes in behavior and the impact of training on the participants are still not in accordance with the established criteria. However, still it is in the category of quite effective with the criteria set from effective to very effective. The purpose of the training was to enable the participants make radio and television-based teaching materials in accordance with the subjects teach.

At the end of the training, not all participants produced the teaching materials appropriate to their respective subjects. With the lack of the optimal program objectives, it can be concluded that the training in the development of radio and television-based learning media did not achieve the goals previously set.

The design model of a levelled learning system is considered suitable to solve the gap problem of this training. The levelled training system and the new manufacturing phase are done face to face. All training materials can be mastered by the participants through the online learning system. The face-to-face meetings can be focused on the practice of making radio and television-based learning media. Overall, the training on the development of radio and television-based learning media implemented by Pustekkom is quite effective and can be advanced with several improvements.

\section{References}

[1] Sari, Delila Batubara: "Kompetensi Teknologi Informasi danKomunikasi Guru SD/MI (Potret, Faktor-faktor, dan Upaya Meningkatkannya", Jurnal Madrasah Ibtidaiyah, Vol. 3 No. $1,(2017)$

[2] Saglik, Mediha: "Television as An Educational Technology: Using Television at Open Education Faculty, Anadolu University, Turkish", Journal of Distance Education-TOJDE, Vol. 2 No.1, (2011)

[3] Master, Kens:“Edgar Dale’s Pyramid of Learning in Medical Education: A literature Review", Medical Teacher, Vol.35 No.11, (2013)

[4] Sharmaa, Shipra: Shalini Gargb, \& Sanjiv Mittalc., "Impact Analysis of ICT Teaching 
Aids Used for Training and Development of Employees”, Journal Procedia - Social and Behavioral Sciences, (2015)

[5] Pusat Teknologi Informasi dan Komunikasi Pendidikan (Pustekkom), Kementerian Pendidikan dan Kebudayaan, Rencana Strategis Pustekkom 2015-2019, Jakarta: Pustekkom, (2015.)

[6] Pusat Teknologi Informasi dan Komunikasi Pendidikan (Pustekkom), Kementerian Pendidikan dan Kebudayaan, Rencana Strategis Pustekkom 2015-2019, Jakarta: Pustekkom, (2015)

[7] Wirawan: Evaluasi: Teori, Model, Standar, Aplikasi, dan Profesi (Contoh Aplikasi

Evaluasi Program Pengembangan Sumber Daya Manusia, Program Nasional Pemberdayaan Masyarakat (PNPM) MandiriPerdesaan, Kurikulum, Perpustakaan dan Buku Teks. PT Rajagrafindo Persada: Depok, (2012)

[8] Firmansyah, Rahayu, W. , \& Nurjannah: Program Evaluation; Entrepreneurship Education through Extracurricular Activities of Student Company. American Journal of Educational Research, 6(7), 957-962, (2018).

[9] Musa, Saburi: Evaluasi Program Pembelajaran dan Pemberdayaan Masyarakat. Bandung: Y-Pin Indonesia, (2005)

[10] Rutman, Leonard: Evaluation Research Methods: A Basic Guide. (California: Sage Publication, (1 985)

[11] Provus, Malcolm, M.: The Discrepancy Evaluation Model: An Approach to Local Program Improvement and Development, Washington D.C Department of Health, Education \& Welfareoffice Of Education, (1969)

[12] Kirkpatrick, D.L., \& J.D. Kirkpatrick: Evaluating Training Program, San Fransisco: Berret-Koehler Publisher, Inc., (2006)

[13] Kirkpatrick, D.L., and James D. Kirkpatrick: Transferring Learning to Behavior: Using the Four Levels to Improve Performance, USA: Berrett Koehler Publishers, (2009)

[14] Matthew B. Milles dan A. Michael Huberman: Analisis Data Kualitatif, terjemahan Tjetjep Rohendi Rohid ,Jakarta: UI-Press, (1992)

[15] Kirkpatrick, D.L., \& J.D. Kirkpatrick: Evaliating Training Program, san Fransisco:

Berret-Koehler Publisher, Inc., (2006)

[16] A. Benny, Pribadi: Desain dan Pengembangan Program Pelatihan Berbasis Kompetensi, Jakarta: Prenada Media Group, (2016)

[17] Brandt, Information Technology Literacy: Task knowledge and Mental Models. Library trends, Institute of Education Research (ERIC), Vol. 50.1, (2001) 